\title{
Efficiency Evaluation of Public Rental Housing Policy Based on DEA
}

\author{
Hua Liu ${ }^{\text {a }}$, Wenmei Pan ${ }^{b}$ \\ School of management, Xi'an University of Architecture and Technology, Xi'an 710065 China
}

alhxjd@foxmail.com, bpanwenmei7@163.com

\begin{abstract}
Public rental housing policy is an important strategy to solve the problem of housing residents, not only the livelihood of the people, but also the policy of housing security system. In this paper, the efficiency of the operation of the public rental housing system in some cities of our country is evaluated by the method of DEA. The analysis shows that the efficiency of the public rental housing system in China is not due to the shortage of capital investment, which is mainly due to the unreasonable allocation of investment funds and the low efficiency of capital operation.
\end{abstract}

Keywords: Public rental housing system; DEA; System efficiency.

\section{Introduction}

In recent years, with the continuous improvement of the housing security system in China, the housing difficulties of urban low-income groups have eased to some extent. However, due to rising house prices, the city's low-income people in an awkward position. They can not afford the higher prices of general commodity housing, and does not comply with the application of urban housing conditions, truly become urban housing problems in the "sandwich layer". At the same time, with the continuous development of urbanization in our country, the living conditions of migrant workers also need to be improved. ${ }^{[1]}$

In order to solve the housing problems in the "sandwich layer" of the city, the government introduced the "Public rental Housing Policy" as an important measure to adjust the structure of housing supply. From the practical point of view of the development of public rental housing construction, the main bottleneck restricting the development of public rental housing is funding problems. Whether the construction funds raised can be effectively utilized is an important standard to evaluate the merits and disadvantages of the public rental housing system. In order to better evaluate the efficiency of the public rental housing system, this article start from the current situation of the construction of public rental housing in some areas of our country, using data envelopment analysis method to evaluate the fund and construction of public rental housing in some cities, to study on the validity of the public rental housing system and analyze the differences and reasons of the efficiency of public rental housing system in cities. This paper will provide a theoretical and empirical basis for our public rental housing system.

\section{Research summary on efficiency evaluation of public rental housing system}

Foreign public rental studies earlier than us, and the results of a lot of research. To ensure the housing needs of low-income persons, foreign governments implemented the housing security system, including public housing. The system efficiency of public rental housing is generally concentrated in the role of the government, the system design methods, financing channels and so on. Arthur O'Sullivan believes that the efficiency of monetary subsidies for low-income people is better than the physical subsidies. ${ }^{[2]}$ Foreign scholars have paid close attention to the efficiency of public rental housing system in China. Through the study of the Beijing housing system, Mark Dula believes that the housing system can not meet the real moderate income people, should promote the construction on process of rental housing. ${ }^{[3]}$ Through the analysis of domestic public rental housing research literature, we found that the current domestic research mainly focuses on the development of public rental housing, the functional positioning, the foreign experience summary and reference, the sustainable design and evaluation methods and other hot spots. Yang Gang made an empirical analysis on the effect of using housing provident fund to construct public rental house in Shanghai 
city. ${ }^{[4]}$ In the public rental housing system, the sustainable development research is mainly based on sustainable development theory. Song Xianglai made an empirical analysis of the economic feasibility of public rental projects. ${ }^{[5]} \mathrm{Li}$ Daoming established a public rental project cost analysis and control model. And for the efficiency evaluation of the public rental housing, the current academic research is less, mainly has the following representative literature. Zhong Zhifeng pointed out that the social capital of the public rental housing construction is not high, the reason is that the investment income is not sure set, the payback period is long, the withdrawal mechanism is not clear and so on. To encourage social capital investment in public rental housing construction should be in the guarantee of land supply, tax relief and other aspects of the positive attempt. ${ }^{[6]}$ Liu Ying compares the advantages and disadvantages of the public rental housing system, and points out that the land supply mode innovation, local laws and regulations conflict, the supervision is the potential problems of public rental housing construction. Pan Yuhong based on DEA method with the public rental housing rental research, points out that lottery housing allocation method is not very well solve the problem of the allocation of public housing. As a common method of efficiency evaluation, DEA has been widely used in various institutional efficiency evaluations, but is not used in the public rental housing System efficiency evaluation. In the existing literature, it has not been a scholar to use the DEA method to evaluate the efficiency of the public rental housing system. This paper tries to analyze the efficiency of the urban public rental housing system from the perspective of the efficiency of the input and output efficiency of public rental housing with DEA evaluation method.

\section{Introduction to DEA model}

The data envelopment analysis method is put forward by Chains in 1978, which is based on the relative efficiency of the input and output method. The core idea of this method is to evaluate the relative effectiveness of multiple inputs and outputs units by using the mathematical programming method. The advantage of DEA is that it is possible to use different decision making units to produce possible boundaries, to measure the relative efficiency of DMU sets. This method is independent of the parameter estimation and weight determination, and the evaluation results are independent of the index. DEA evaluation method is widely used in the analysis of the relative effectiveness of different industries and enterprises. Zhang Jianhua uses DEA to make an empirical study on the efficiency of Chinese commercial banks, and the efficiency of input and output efficiency of the science and technology industry was analyzed by DEA method by Xu Zhi and Shi Ping. The two basic models of DEA are CCR model and BCC model, the CCR model is mainly to measure the overall efficiency of the decision-making unit, and the BCC model is mainly to measure the technical efficiency. Therefore, this paper will mainly use the CCR model to evaluate the efficiency of China's first tier cities.

\section{Efficiency evaluation of urban public rental system in China}

1. Index selection. Depend on the Opinion of the State Council on resolving the housing difficulties of urban low-income families, Ministry of housing promulgated Public Rental Housing Management Approach in 2012. Various local governments have also introduced a detailed public rental housing construction and management approach, the main source of funds for the public rental housing is not less than $10 \%$ of the land leasing, financial funds, provident fund value-added benefits, social capital and other channels to raise funds. So this study put land leasing, financial funds, provident fund value-added benefits and social invested as DEA input factor, the physical distribution rent efficiency, the actual efficiency of housing subsidies and rent reduction degree as output factor to evaluate the first city public rental system efficiency.

2. Result analysis

(1) City overall efficiency analysis. The comprehensive efficiency of DEA is made up of two parts. Comprehensive technical efficiency $=$ Pure technical efficiency $\times$ Scale efficiency. Pure technical efficiency is the production efficiency of enterprise's technology and management, while the scale 
efficiency is the result of the scale factor of the enterprise. Comprehensive technical efficiency is a comprehensive evaluation of the decision-making unit of resource use efficiency, resource allocation, and other aspects of capacity. The overall efficiency of first cities is estimated by the CCR model, as shown in Table 1.

Table 1 The efficiency ranking of public rental housing system in cities

\begin{tabular}{|c|c|c|}
\hline Ranking & Cities & DEA efficiency value \\
\hline 1 & Beijing & 1 \\
\hline 1 & Shanghai & 1 \\
\hline 1 & Chongqing & 0.9 \\
\hline 4 & Guangzhou & 0.88 \\
\hline
\end{tabular}

From table 1 can be seen in the selection of the first cities in the sample, Beijing, Shanghai and Chongqing are DEA effective areas. Effective DEA shows that the efficiency of the public rental housing system in the above three areas has reached the best scale and efficiency. Guangzhou and Tianjin are the weak DEA regions, the DEA efficiency of Guangzhou is 0.9, Tianjin's DEA efficiency is 0.88 , which shows that the two regions of the technical efficiency and scale of income can not be reached the best state, and there may be a certain degree of assets idle.

(2) Scale benefits analysis. From table 2, we can see that Guangzhou and Tianjin two are the increase in scale revenue cities, which shows the increase of public rental housing investment for the relief of housing difficulties of urban specific income groups have a positive effect. Moreover, this also means that these areas of the public rental housing efficiency can not only rely on increasing the support of the investment, we must be combined with the actual local public rental housing idle funds to effectively adjust the operating structure, in order to improve the efficiency of public rental housing. Although Chongqing is a city of system efficiency, also is the city of increasing in the scale benefits, so the increase in the supply of public rental can further improve efficiency.

Table 2 Part of the public rental housing scale returns

\begin{tabular}{|c|c|c|}
\hline Scale return & DEA effective cities & Weak DEA Cities \\
\hline Increasing returns to scale & Chongqing & Tianjin,Guangzhou \\
\hline Scale returns unchanged & Beijing,Shanghai & \\
\hline
\end{tabular}

(3) Analysis of input-output of weak DEA Cities. According to the input and output, we can find that the reasons for the weak DEA in some cities. All of the weak DEA areas have a certain surplus of funds, for example, in Guangzhou, there is 17\% surplus of the financial expenditure, and 30\% surplus of land transfer income, and 26\% surplus of the provident fund value-added benefits, and 18\% surplus of social capital , other funds surplus $88 \%$. This shows that the low efficiency of capital investment in Guangzhou, which shows that the lack of investment in the weak DEA city is not the main reason for the low efficiency of the public rental housing system, the government's attention and the legal system is sound, and other reasons are likely to become public rental housing system is running smoothly. Therefore, in the same time to increase investment, accelerate the construction of the legal system, improve the government's attention, which is in the long-term solution to the efficiency of public rental housing system is an important measure!

(4) Analysis of weak DEA urban output. From table 3 can be seen that the output of weak DEA region is in a shortage of state. We can increase the public rental housing subsidies, increase the supply of public rental housing, but also to increase supply by decreasing public housing rent.

Table 3 Analysis of weak DEA urban output

\begin{tabular}{|c|c|}
\hline Output deficiency types & Cities \\
\hline Insufficient fund subsidy of public rental housing & Tianjin,Guangzhou \\
\hline Insufficient subsidy of public rental house & Tianjin,Guangzhou \\
\hline Rent reduction problem & Guangzhou \\
\hline Surplus of public rental housing & Tianjin \\
\hline Surplus of rent & Tianjin,Guangzhou \\
\hline
\end{tabular}




\section{Conclusion}

The main problem of our public rental housing system is the lack of profitability of the public rental housing system itself, the housing security system is not perfect, the government in the supply of land is not high, public rental access and exit mechanism is not perfect and so on. In this paper, the reasons for the low efficiency of some cities are analyzed with the help of the DEA system efficiency evaluation method. Overall, in the observation of the 5 first cities, only 3 regions in the effective state of DEA, but the overall trend of weak DEA city is good.

Through the analysis of the efficiency of public rental housing in the first cities in China, we believe that we should solve the above problems by adjusting the different distribution forms of public rental housing system. Under the premise of the completion of the central government issued a public rental construction tasks, should be combined with the economic development of the local area, the development of suitable local public rental management system, and actively innovative financing mode, to mobilize social capital to participate in the construction of public rental housing, and strive to solve the 'sandwich' housing difficulties!

\section{References:}

[1] Ministry of housing. Guiding Opinions on Accelerating the Development of Public Rental House [Z]. Construction Security [2010] No.87.

[2] Arthur•O'Sullivan. Urban Economics [M].Beijing: CITIC Publishing House, 2003:56.

[3]Mark Dula, Xiulan Zhang, and Mingzhu Dong: China's Homeownership-Oriented Housing Policy: An Examination of Two Programs Using Survey Data from Beijing[R]. Harvard University, Joint Center for Housing Studies. 2005.

[4]Yang Gang, Wang Hongwei. Study on the Impact of the Fund System on the Fluctuation of the Housing Market in Shanghai [J]. Journal of Shanghai University of Finance and Economics, 2012 (1):85-91.

[5]Song Xianglai. Policy Analysis of Public Rental Housing from the Perspective of Economic Evaluation-Case Study Based on D City of L Province [J]. Building Economy, 2011(11):55-58.

[6]Zhong Zhifeng. Empirical Research on the Construction of Social Capital in Public Rental Housing [J]. Urban Development Research, 2013(4):29-33. 